\title{
The musical image of Vajra Guru Mantra in «Sacred Chants of Buddha» album by Craig Pruess
}

\author{
Ekaterina V. Mosman* \\ Krasnoyarsk State Institute of Art \\ 22 Lenin Str., Krasnoyarsk, 660049, Russia
}

Received 12.11.2015, received in revised form 29.11.2015, accepted 05.01.2015

The paper describes the features of realization of Vajra Guru Mantra by the European composer Craig Pruess. The author analyzes the timbre, texture, modal and structural characteristics, identifying the features which allow referring the composition to the genre of popular meditative music.

Keywords: meditative music, Vajra Guru Mantra, Craig Pruess, Buddhism, raga.

DOI: 10.17516/1997-1370-2016-9-1-203-209.

Research area: culture studies.

The album «Sacred Chants of Buddha» by Craig Pruess, released in 1999, includes 4 pieces with Buddhist mantras, namely «Vajra Guru Mantra» (15:35), «Buddham Sharanam» (15:54), «Om Mani Padme Hum» (15:22) and «Om Tara» $(15: 40)$.

According to the information, provided on the official website of Craig Pruess, after the success of the album "Sacred Chants of Shiva», the company «Times of India» ordered a series of compositions, "contributing to the immersion in contemplation of the universal spirit of serene beauty". The disk "Sacred Chants of Buddha», which was attached with a colorful eight-page booklet with photographs and guidance for those who wish to use the music in meditation, was also highly appreciated by the audience in India and sold in large and small cities.
In this album Craig Pruess acted not only as a music writer and arranger, but also as a performer of three vocal tracks (No. 1, No. 2, No. 4). The singer Pundit Vishwa Prakash, who is famous in India, was invited to render «Buddham Sharanam».

This paper discusses the features of the realization of Vajra Guru Mantra, which is one of the most important in Vajrayana Buddhism ${ }^{1}$, by the popular means of meditative music ${ }^{2}$. Its lyrics («OM A HUM VAJRA GURU PADMA SIDDHI $\left.H U M »^{3}\right)$ is sung in the first issue of the album «Sacred Chants of Buddha», repeating 31 times $^{4}$.

The chant of the mantra is preceded by an instrumental entrance, containing elements of tone-painting. Flowing transit $\operatorname{sitar}^{5}$ figures in the high register, as if shimmering with delicate rainbow colors of the unearthly world, coupled

(C) Siberian Federal University. All rights reserved

* Corresponding author E-mail address: gurfield@mail.ru 
with shimmering jingling bells $s^{6}$, create an image of "miraculous lights" that can be interpreted as a phenomenon of a gold scroll with the sacred text of Vajra Guru Mantra ${ }^{7}$ inscribed on it.

The pedal tones of singing bowls ${ }^{8}$ and tampura $^{9}$ in a great octave, emerging later, find boundless depths of the unknown space. Due to a wide arrangement of voices, radiant "glimpses" of sitar and bell sounds, as well as special sound processing, musical fabric is like "illuminated" from within.

The theme, acceding later, which is performed with a duduk ${ }^{10}$, because of a melodic relief and a "thicker" tone of this instrument in the actuated register (within the fifth $g-\mathrm{d} 1$ ), is sounder, and as if marks the next stage of the thickening of a metaphysical phenomenon, which manifests itself in the material world. This effect is compounded by the fact that the sound of the duduk resembles the human voice by its tone.

A slowly unfolding melody of the duduk, with a "dissolved" calling intoneme, is articulated from small thin melodies with lots of decorations (sliding, mordents, trills, grace notes) and "hanging" endings of motives. A high position of some sounds is difficult to "percept", so the recording of a music example is rather conventional: "flickering" of the tones $b$ and $h$ in double measure is aurally perceived as "average". The elements of gritty voicing which is typical for the early folklore of all nations, as well as for professional music of oral traditions of the East, contribute to the creation of an archaic flavor. In addition, it is promoted by metrorythmical freedom, rhythmical and structural flexibility (the division into bars, fixed in a musical example, is also conventional) (Fig. 1).

The texture complex, set in the entrance, is essentially the same over the entire composition, serving as a background for the deployment of vocal and instrumental themes of the following sections.

This is a fixed base, which is "strung" by the sound of other instruments - lasting tones of a singing bowl and tampura forming a combination of perfect consonances - octaves and fifths. These are the first intervals of a natural line, begotten objectively by any sounding body, having the semantics of timeless natural, cosmic being in music. In the aspect of pitch organization a fifth "organ point" gives the impression of the abutment of the tone " $\mathrm{C}$ ".

Besides, the Bourdon fifth accompanying the melody of the entrance is associated with an accompaniment to Indian raga, which, along with the modal characteristics of the melody, not only gives a more exotic "flavor" to the sound, but is seen as a sign of refraction of the harmony of the universe through the prism of the ancient musical culture.

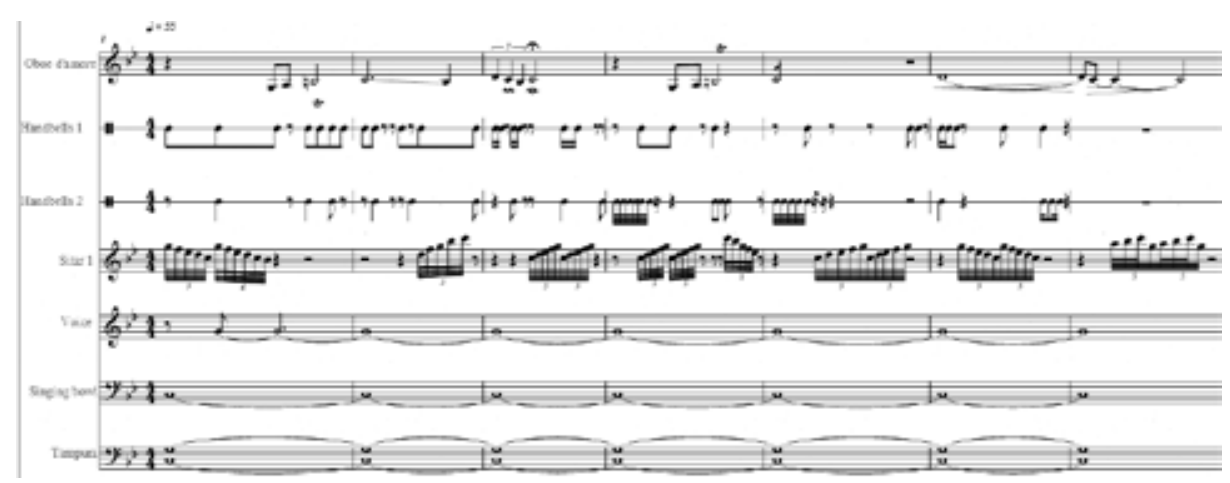

Fig. 1 


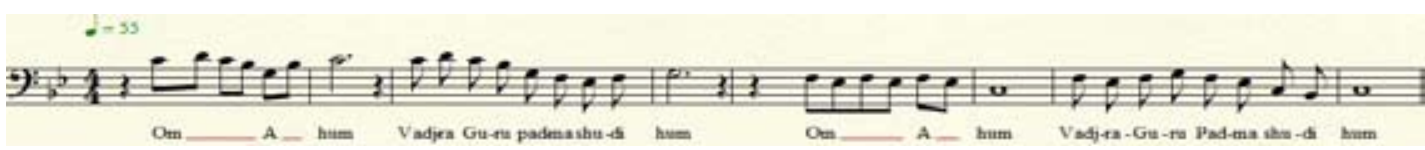

Fig. 2

In addition to the sustained pedal sounds of the tampura and singing bowls, tinkling bells at random rhythm, scale-wise and arpeggiated passages of a sitar in small lengths, it includes the subtle "rumblings" of electronic instruments, as well as "natural" sounds, contributing to the sense of boundless space: a roar of a surf, noises of stones, rolled by a wave, a breath of wind.

Despite the abundance of voices, the invoice is not "overloaded" - the feeling of "air environment" is saved due to the predominance of middle and high registers and a large distance between the voices, their alternating entrance and discreet withdrawal.

Taking into consideration constant basic textural features, we should note continuous microtransformations and the mobility of the components of the musical fabric, with regard to the number of voices, high pitch composition and "graphics" of configurational sitar passages and an intricate rhythmic bell pattern. The combination of monotony, uniformity, ostinato and variance, material update and procedurality corresponds to the Buddhist principle of permanence in the volatility and peculiar to all the works included in the genre of popular meditative music ${ }^{11}$.

The ease and graduality of melodic development of a duduk theme define the features of its syntactic organization: each time a new scale-structural variant (the entrance theme marked in the diagram as "A", with a few changes sounds throughout the composition three times).

The chant of the mantra (vocal sections are indicated in the diagram as " $\mathrm{B}$ ") is characterized by a smooth melodic pattern, regularity, rhythmic uniformity, the lack of individual, characteristic features. The singer's voice sounds a bit detached, one might even say - dull, outputting the sound in a "transpersonal plan", allowing listeners to focus on the actual sacred text of the mantra.

Supra-individual, objective character of the melody is also created by the lack of modal gravity and pentatonic elements. The basis of short melodic cells can include a conjunct motion, trichords in a quart or adhesion of these elements. Some similarity with the entrance melody is provided by "hanging" endings-"dots". The lack of halftone moves, tensions, a quartofifth "backbone" of melodic units, variability of fret supports are the signs of an anhemitonic modal structure that is the oldest stage in the development of modal thinking of many people (Fig. 2).

At the heart of the tune is common time melody ${ }^{12}$, which alternatively transforms further. Its variants-motifs are arranged in pairs ${ }^{13}$ (their pair is a conditional common time designated in the diagram as «b», and it is a full mantrachant). Logically the pairs of melodies (a kind of periodicity pair) are secured on the basis of a question-and-answer structure: the first sentence is higher in tessitura and ends with an upward swing onto an unstable step of a fret, while the second one includes a downward motion to a sustainable step of a fret in the lower register; but some sections have not two, but three pairs of melodies' variants, i.e., the text of the mantra sounds three times (in the final stanza - four times).

In addition to the theme of the duduk, the composition contains another instrumental melody, sounding in the timbre of a synthesized 
vocal (which we conventionally designated as "angelic voice") on the background of the already mentioned textured complex (in the section indicated in the diagram as "C"). The melodic line is symmetric and is built on two descending fourth melodies-"sequents" by straight lengths, which are based on a simple modal structure of four tones in the range of a fifth. The simplicity and an objectified tone of the melody, the dimension of a rhythmic pattern, descending "calling" quartal ${ }^{14}$ motives (forming a four-step scale in the range of a fifth), high register, transparent texture and soft dynamics contribute to the creation of a "heavenly", "ethereal" image. In further moments the theme recedes into the background, "getting lost" in the texture and connecting with the main theme (Fig. 3).

Here is the compositional scheme of the play. It identifies letter names of the sections (the first line) and their playing time (the second line), as well as the themes, included in the sections with a more detailed playing time (the third and fourth lines) (Fig. 4).

As you can see, the whole composition is mostly based on the alternation of the themes considered above, with their repeated return and combination in a vertical way.

The arrangement of vocal sections contributes to their bigger weight compared with instrument ones - primarily due to a more expanded scale, the presence of a text and a more clear structure. The vocal sections are relatively complete, circumscribed constructions which are similar to stanzas. Each stanza includes two or three musical phrases (four - in the final stanza).

Taking these two factors into account, we can talk about a free realization of the principle of rondo, where the function of ritornel is performed by vocal sections and the function of episodes - by instrumental ones. However, the tonal harmonic sections are not opposed, on the contrary, we note the similarity of their modal base and, as a consequence, their intonation relationship. At

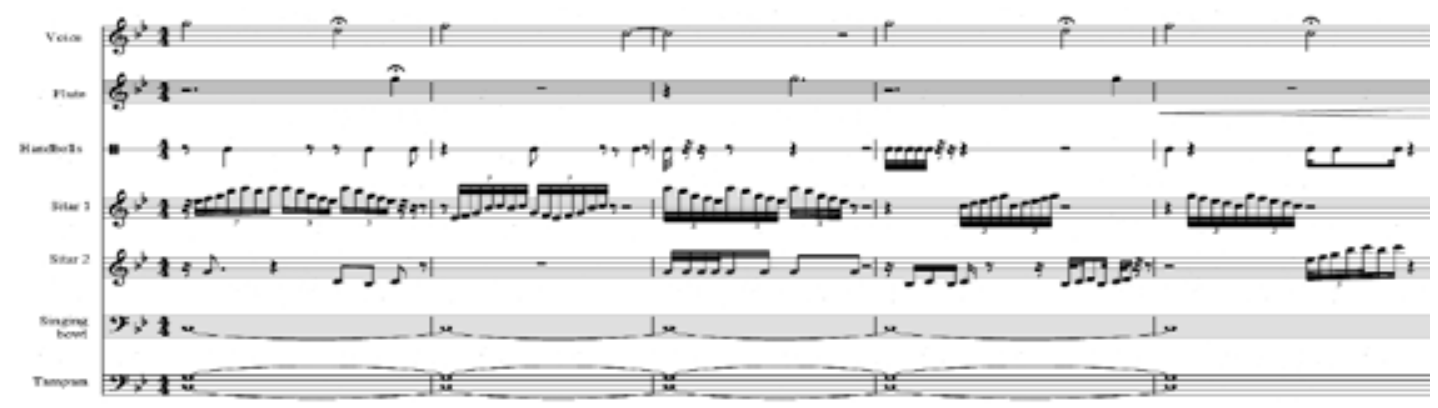

Fig. 3

\begin{tabular}{|c|c|c|c|c|c|c|c|c|c|c|c|c|c|c|c|c|c|}
\hline$A$ & \multicolumn{2}{|c|}{ B } & $A$ & \multicolumn{3}{|c|}{ B } & C & \multicolumn{4}{|c|}{ B } & $A$ & $\mathrm{C}$ & \multicolumn{3}{|c|}{ B } & C \\
\hline $40^{-1}$ & \multicolumn{2}{|c|}{$1^{\prime} 18^{\prime \prime}$} & $40^{\prime \prime}$ & \multicolumn{3}{|c|}{$233^{\prime \prime}$} & $1^{\prime} 43^{\prime \prime}$ & \multicolumn{4}{|c|}{$3^{\prime} 12^{\prime \prime}$} & $32^{\prime \prime}$ & $48^{\prime \prime}$ & \multicolumn{3}{|c|}{$2^{\prime 254^{\prime \prime}}$} & $1^{\prime} 18^{\prime \prime}$ \\
\hline$A$ & $\omega_{1}$ & $\omega_{1}$ & A & $b b_{1}$ & $b_{1} b_{1}$ & $\omega_{1} b_{1}$ & c & ${ }_{C}^{b t_{1}}$ & $\begin{array}{c}\mathrm{bb}_{1} \mathrm{~b}_{1} \\
\mathrm{c}\end{array}$ & $\boldsymbol{\phi}_{1}$ & ${ }_{C}^{b} b_{1} b_{1}$ & A & $\mathbf{c}$ & $\begin{array}{c}\boldsymbol{\phi}_{1} \\
\mathrm{c}\end{array}$ & ${ }_{c}^{b b_{2} b_{1}}$ & $\mathrm{Bb}_{1} \mathrm{~b}_{\mathrm{C}} \mathrm{b}_{1}$ & c \\
\hline $40^{\prime \prime}$ & $40^{\prime \prime}$ & $38^{\prime \prime}$ & $40^{\prime \prime}$ & $36^{\prime \prime}$ & $1^{\prime}$ & 57 & $1^{1} 43^{\prime \prime}$ & $40^{\circ}$ & 1 & $37^{\prime \prime \prime}$ & $55^{\prime \prime}$ & $32^{\prime \prime}$ & $48^{\prime \prime}$ & $38^{\prime \prime}$ & $58^{\prime \prime}$ & 1'18" & $1^{1} 18^{\prime \prime}$ \\
\hline
\end{tabular}

Fig. 4 

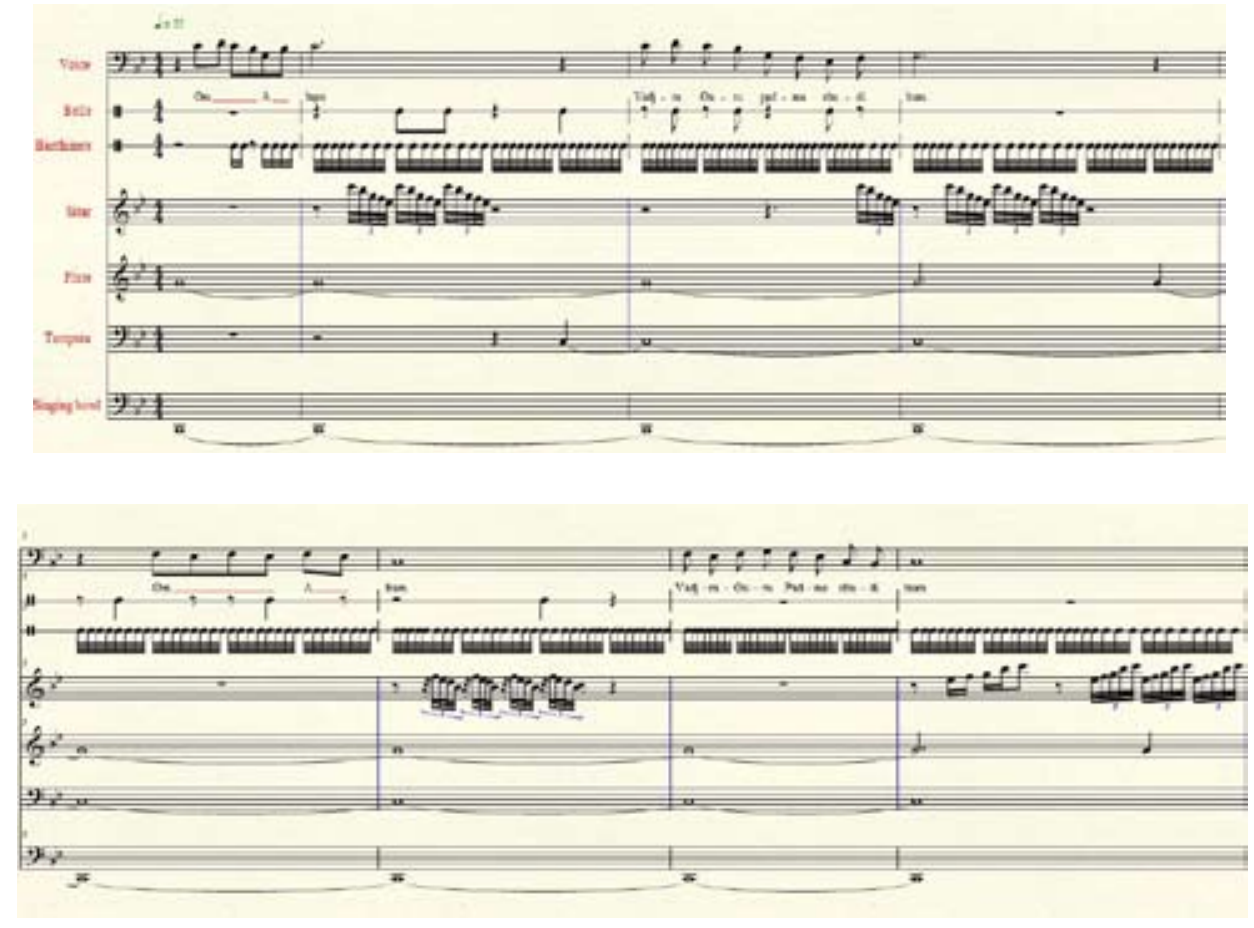

Fig. 5

the same time, the entire thematic material (both in "micro" and "macro" levels) is subjected to variation-variational transformations: the themes in their original form are not repeated, but both their syntactic structure and timbre, rhythmic and textural components change (Fig. 5).

The principle of symmetry, realized at different levels (from melodies within the same phrase to whole stanzas), as well as constant repetitions of melodies, phrases, sentences, chapters, contribute to the effect of "gyre", statics. The sense of time dilation is created due to a progressive massive growth of stanzas, and therefore vocal sections as a whole. Thus, we can talk about a special organization of time which is not linearly directed, but cyclic and closed. "Space-time continuum", recreated by the musical means, addresses the consciousness of the listener to a kind of "supra-temporal" reality.

In this composition, we do not see the thematic transformation, the accumulation and display of its new features. At the same time, despite the lack of a dynamic procedurality, there is a certain direction in the succession of the sections at the figurative-semantic level in general - from the entrance image of "miraculous lights" and "calling" duduk music to the sacred text of the mantra, which is the semantic center of the composition. The transformation of the instrumental theme ("C") in the final section, namely its fragmentation into short disparate motives, "scattered" in the texture, the gradual removal of all voices, except for pedal tones, the extinction of dynamics and "melting" of the sound can be interpreted as a metaphor of the dissolution in infinity and merging with the divine.

The inclusion of the text of Tibetan mantra in the composition indicates the influence of the spiritual practice of Buddhism. But above all, popular meditative music is an artistic phenomenon. The aesthetic functions turn out to 
be prevailing - the composer as if gives listeners the opportunity to hear "music of the spheres", to feel peace and harmony with themselves and the world around them.

\footnotetext{
The genre area of popular meditative music covers instrument theatrical (at least - vocal) pieces, common in a fixed form in audio data carriers and having a number of similarities in figurative-content terms and in terms of musical language, existence and functioning. (Matviitseva, 2014, p. 103-111)

2 The followers of the Nyingma School consider it basic. The Mantra text was handed over by Guru Rinpoche, or Padmasambhava, the Indian Buddhist tantra teacher of the VIII century, revered in Tibet. Padmasambhava created a line of oral transmission (Kama), which goes from teacher to student, and left a number of hidden teachings (terma). Terma with the interpretation of the text of Vajra Guru Mantra was discovered by Tulku Karma Lingpa (Khenchen, Khenpo, 1999, p.36).
}

3 The unambiguous interpretation of the syllables of the mantra is not possible, its content is multifaceted. In order to illustrate Vajra Guru Mantra in general terms (to the extent that is necessary for this paper), we turned to the publication of "The source of achievements. The benefits from reading Vajra Guru Mantra, and an explanation of its syllables". As follows from the text of this book, Vajra Guru Mantra contains a life and heart essence of all the Buddhas of the three times, enlightened Teachers, deities, dakinis, and protectors of Dharma (Teachings). That is why a good effect of Vajra Guru Mantra is multidimensional: it protects those who diligently practice its reading against all kinds of adversity and helps to overcome various disasters, achieve abundance and prosperity, develop their spiritual faculties, become purged from defilements and find the original knowledge.

4 Apparently, the composer did not aim to observe the principle of japa, as the number of repetitions of the mantra does not meet the Buddhist sacred numbers $(9,27,36,108$, etc.)

5 Sitar is a fretted instrument used in Indian classical music and characterized by a particular unique and recognizable timbre.

6 Buddhists believe bells harmonize space. Bells are used in Buddhist rituals.

7 Terma with Vajra Guru Mantra was discovered in the XIV century in Tibet by Tulku Karma Lingpa.

$8 \quad$ Singing bowls are a fixed musical instrument, a kind of bell. The sound comes from vibration of a bowl's walls and its edge.

9 Tampura is a string-bowed instrument. In India it is used mainly as an accompanying instrument in the performance of raga.

10 Duduk is a woodwind musical instrument, common among the peoples of the Caucasus and the Middle East.

11 In broader terms, this is due to the parameters of time, specific to this genre, which is not linearly directed, current from the past through the present to the future, but not having the beginning and the end; not a motion-action, but a stay.

12 Melody is the smallest syntax element, a melodic invariant whose formula operates outside of this text. Melody is also a particular variant, an invariant and an archetype. Besides, it is a specific link in the melody chain, and a subject of variant development in the text or a type of texts (Ruch'evskaia, 1998, p. 27-28).

13 A pair of variants of a melody for hearing, brought up on European classics, is correlated with a melodic phrase. Due to the regularity of common time constructions and the distant link of the reference tones enclosing them, the analogy with the structure of a period of two (three or four) sentences is possible.

14 «Intonational form of music», the book of Medushevskii, contains a reference to a quart which is presented as leitinterval of angels in "Christmas Oratorio" by Bach. (Medushevskii, 1993, p. 37).

\section{References}

Khenchen P. Sh., Khenpo C.D. Svet trekh dragotsennostei [The Light of Three Treasures]. Moscow, 1999. 128 p.

Matviitseva E.V. Genre Field of Popular Meditative Music as the European Cultural Phenomenon of Modern Time. Journal of Siberian Federal University. Humanities \& Social Sciences, 7 (1), 2014. p. 103-111.

Medushevskii V.V. Intonatsionnaia forma muzyki [Intonational form of music]. Moscow, 1993. $262 \mathrm{p}$.

Padmasa $\square$ bhava. Istochnik dostizhenii. Blaga ot chteniia Vadzhra guru mantry i ob" iasnenie ee slogov [The source of achievements. The benefits from reading Vajra Guru Mantra, and an explanation of its syllables]. Moscow, 2013. $111 \mathrm{p}$.

Pruess C. Official page, available at: http://www.heaven-on-earth-music.co.uk/album3.html (accessed September 8, 2014). 
Ruch'evskaia E.A. Klassicheskaia muzykal'naia forma [Classical musical form]. St. Petersburg, 1998. $268 \mathrm{p}$.

\section{Музыкальный образ Ваджра Гуру мантры \\ в альбоме Крейга Пресса \\ «Sacred Chants of Buddha»}

Е.В. Мосман

Красноярский государственный институт искусств Россия, 660049, Красноярск, ул. Ленина, 22

В статье рассмотрены особенности претворения Ваджра Гуру мантры европейским композитором Крейгом Прессом. Автор анализирует тембровые, фактурные, ладовые, структурные характеристики, выявляя особенности, позволяющие отнести эту композищию $\kappa$ жанровой сфере популярной медитативной музыки.

Ключевые слова: медитативная музыка, Ваджра Гуру мантра, Крейг Пресс, буддизм, рага.

Научная специальность: 24.00.00 - культурология. 